\title{
Characterizing the Sphaceloma Fungus, Causal Agent of Superelongation Disease in Cassava
}

\author{
Elizabeth Alvarez, Plant Pathologist, and Martha L. Molina, Research Assistant, International Center for Tropical \\ Agriculture (CIAT), A.A. 6713, Cali, Colombia
}

\begin{abstract}
Alvarez, E., and Molina, M. L. 2000. Characterizing the Sphaceloma fungus, causal agent of superelongation disease in cassava. Plant Dis. 84:423-428.

The fungus Sphaceloma manihoticola causes superelongation disease in cassava, a starchy root crop grown widely in the tropics. Isolates were collected from infected plants grown in six localities of Colombia. Morphological analyses of the fungus showed that colony growth and color are not stable characteristics over time. Pathogenicity studies, using the susceptible cassava variety M Col 22 and the resistant M Ven 77, showed that M Col 22 was tolerant of $29 \%$ of pathogen isolates studied and had an intermediate reaction to $71 \%$. Variety M Ven 77 also showed tolerance of $16.2 \%$ of the isolates, had an intermediate reaction to $80.6 \%$, and was susceptible to $3.2 \%$. Significant cultivar $\times$ isolate interactions indicated pathogenic specialization. This study is the first to describe this pathogen's molecular characteristics. A homogeneous and reporducible band of about 545 bp was obtained with polymerase chain reaction which, when digested by restriction enzymes, showed an equal pattern of bands for all isolates. The isolates thus belonged to one species. Random amplified polymorphic DNA analysis revealed intraspecific genetic diversity. By better understanding the pathogen, we can apply more appropriate disease management strategies, such as selection of germ plasm tolerant of superelongation disease.
\end{abstract}

For thousands of years, cassava (Manihot esculenta Crantz) has been a basic agricultural crop in the tropics. Archeological evidence indicates that it was cultivated in Peru about 4,000 years ago and was one of the first crops to be domesticated in America (6). Cassava is cultivated mainly for human consumption, but it is also important as animal feed and has significant industrial use (5). The world production of cassava rose from 70 million tons in 1960 (4) to 159 million tons in 1998, the total harvested area being 16 million hectares. Countries with the highest cassava production are Nigeria, Brazil, Zaire, Thailand, and Indonesia (7).

In Colombia, cassava is cultivated in almost all departments, from sea level to 2,000 meters. About $38 \%$ of commercial production is found in the seven departments of northern Colombia that together make up the "North Coast," as the region is locally known. Other significant produc-

Corresponding author: Elizabeth Alvarez E-mail: e.alvarez@cgiar.org

This work was supported by the United Nations Development Programme grant GLO/91/013/A/ 011/31. "Ecologically Sustainable Cassava Plant Protection in South America and Africa: An Environmentally Sound Approach."

Accepted for publication 1 December 1999.

Publication no. D-2000-0201-01R

(C) 2000 The American Phytopathological Society tion is found in the hilly Andean region (15). The fungus Sphaceloma manihoticola, the causal agent of superelongation disease in cassava, was described for the first time in 1950 by Bitancourt and Jenkins (2), who emphasized host symptomatology and pathogen morphology. In Colombia, the disease was reported for the first time during outbreaks in 1972 (3). In 1976, Krausz (9) confirmed that S. manihoticola causes superelongation. Typical symptoms of the disease are an exaggerated lengthening of internodes in young stalks and petioles, caused by the hormone gibberellin $\mathrm{A}_{4}$ (18); a deformation or involution of young leaves; and the presence of cankers in stalks, petioles, and leaf blades (3). Superelongation is considered a major disease of the crop because it affects stake (i.e., planting material) quality and, when severe, drastically reduces yields. The causal organism is easily dispersed by wind and water and disseminated through the use of infected stakes as seed. Such easy dispersion and the possible existence of physiological races or biotypes of the fungus are two aspects that hinder management of the disease (16). Previous studies have demonstrated variability of morphology and pathogenicity in the fungus (17), but its genetics are still unknown.

The objectives of the study were to colfected by superelongation disease, determine the variability of morphology and pathogenicity of these isolates, and to conduct a preliminary, molecular characterilect isolates of the fungus from plants af- zation of the fungus to determine its genetic diversity.

\section{MATERIALS AND METHODS \\ Collecting isolates of Sphaceloma manihoticola. Collecting samples. Sam-} ples were collected from plants affected by superelongation disease and showing symptoms on leaves, petioles, and stems. The isolates came from six localities in Colombia, according to three edaphoclimatic zones: Zone I = Carmen de Bolívar (in the Department of Bolívar); Zone II = Carimagua, Puerto López, Granada, and Villavicencio (in the Department of Meta); and a transitional zone = Santander de Quilichao (in the Department of Cauca), which corresponds to an area between Zone II and another zone (V) (Table 1).

Isolating the pathogen. The pathogen was isolated from cankers that were removed from the plant with a sterile scalpel and disinfested with undiluted household bleach (5\% sodium hypochlorite) for 60 to $90 \mathrm{~s}$. They were then rinsed with sterile distilled water for $30 \mathrm{~s}$ and dried with sterile absorbent tissue. The disinfested samples were placed on fresh potato dextrose agar (PDA) medium, prepared as follows: $200 \mathrm{~g}$ of fresh potatoes were washed, diced, and cooked for $10 \mathrm{~min}$ in $300 \mathrm{ml}$ of distilled water. The potatoes and liquid were pureed and mixed with an additional $700 \mathrm{ml}$ of distilled water, $17 \mathrm{~g}$ of dextrose and $18 \mathrm{~g}$ of agar. The mixture was autoclaved for $30 \mathrm{~min}$ and supplemented with 1 $\mathrm{ml}$ of 100-ppm streptomycin sulfate and 1 $\mathrm{ml} \mathrm{25 \%} \mathrm{lactic} \mathrm{acid.} \mathrm{The} \mathrm{plates} \mathrm{were} \mathrm{incu-}$ bated for about 15 days at $26^{\circ} \mathrm{C}$ in the dark. To decontaminate the isolates, a disk of the fungus was put into a solution containing sterile distilled water, 2 drops of $25 \%$ lactic acid, and $0.1 \mathrm{ml}$ of $100-\mathrm{ppm}$ streptomycin sulfate. Subsequently, they were decanted, rinsed three times with sterile distilled water, and dried with sterile absorbent tissue. They were then placed on PDA and incubated at $26^{\circ} \mathrm{C}$ in the dark.

Acquiring monoconidial isolates. For each isolate, a suspension of conidia was prepared to a concentration of $5 \times 10^{1}$ conidia per $\mathrm{ml}$. The suspensions were placed on $2 \%$ water agar and incubated at $26^{\circ} \mathrm{C}$ for 24 to $36 \mathrm{~h}$ in the dark. Subsequently, with the help of a microscopic stereoscope, individual germinated conidia were collected with a fine inoculating needle, placed on PDA, and incubated again at $26^{\circ} \mathrm{C}$ in the dark for about 25 days. Isolates 
were transferred to additional plates containing PDA.

Conserving the isolates. The isolates were maintained in petri dishes on PDA and transferred to new media approximately every 2 weeks. To store the isolates for long periods, we placed them in test tubes on PDA medium and covered them with sterile mineral oil.

Morphological characterization. Monoconidial isolates that were 15 to 20 days old were used. A 5-mm-diameter disk of each fungus was obtained with a hollow punch and placed on PDA. Two replicates per isolate were made, and observations were taken 7,14 , and 21 days after placing on the medium. The morphological characteristics evaluated were: (i) colony growth (length and width), (ii) presence or absence of aerial mycelium, (iii) colony color, and (iv) conidial size (mean of 50 measurements taken per isolate). The morphological characteristics were analyzed by cluster analysis, using Ward's technique, based on minimum variance.

Pathogenicity analysis. The fungus was inoculated onto plants in a growth chamber under controlled conditions. Of the collection, 31 isolates were evaluated in two cassava varieties, the resistant $\mathrm{M}$ Ven 77 and the susceptible M Col 22. A randomized complete block design was used, with 10 replicates per isolate per variety and a control inoculated with sterile distilled water and Tween 20. Pathogenicity was rated according to a scale of 1 to 5 , where $1=$ plants without visible symptoms, $2=$ some spots or cankers on leaves or petioles, 3 = cankers on petioles and stems, severe leaf deformation, 4 = elongation, cankers on leaves, petioles, and stems, and severe leaf deformation with scald, and $5=$ dieback after severe lengthening.

In the greenhouse, 10 -cm-long stakes were planted in pots; the stakes had been cleaned of fungi by immersion for $5 \mathrm{~min}$ in a solution of $0.2 \%$ Sistemin (dimethoate), $0.6 \%$ Captan, and 0.6\% Benlate (benomyl). They were left to dry, then planted, and the aerial extreme of each stake was covered with paraffin. The stakes were planted in a mixture of soil and sand (2:1) and sterilized by steam. Six days after planting, to ensure cleanliness, the stakes received a further application of a solution of $0.2 \%$ Sistemin and $0.3 \%$ Coljap $(\mathrm{N}=30 \%, \mathrm{P}=$ $3 \%$, and $\mathrm{K}=5 \%$ ). To prepare the inoculum, each of 10 samples of each isolate was placed in a petri dish containing PDA medium and incubated for 21 to 28 days at $26^{\circ} \mathrm{C}$ in the dark. The inoculum was obtained by suspending the fungus in sterile distilled water with 5 drops of Tween 20 and adjusting the concentration to $3 \times 10^{6}$ conidia per ml. Each stalk to be inoculated was cleaned with a cotton-tipped applicator and dampened with sterile water to remove the waxy layer for easier fungal penetra-

Table 1. Origin of Sphaceloma manihoticola isolates used in the study. The fungus is the causal agent of superelongation disease in cassava (Manihot esculenta Crantz)

\begin{tabular}{llll}
\hline Isolate & Cassava variety & Plant part & Origina \\
\hline 0001 & M Pse 009 & Stem & Carimagua \\
0010 & CM 523-7 & Petiole & Carimagua \\
0011 & CM 523-7 & Leaf & Carimagua \\
0016 & CM 6633-6 & Petiole & Puerto López \\
0017 & CM 6633-6 & Leaf & Puerto López \\
0018 & M Bra 97 & Petiole & Puerto López \\
0020 & M Bra 97 & Petiole & Granada \\
0021 & M Bra 97 & Leaf & Granada \\
0022 & CM 7274-1 & Petiole & Granada \\
0024 & M Pse 002 & Stem & Carimagua \\
0026 & M Pse 002 & Petiole & Carimagua \\
0033 & M Bra 237 & Stem & Carimagua \\
0035 & M Bra 237 & Leaf & Carimagua \\
0037 & M Col 1795 & Petiole & Carimagua \\
0040 & M Pse 004 & Leaf & Carimagua \\
0041 & M Pse 004 & Petiole & Carimagua \\
0043 & CM 1355-2 & Petiole & Carimagua \\
0046 & M Bra 458 & Leaf & Carimagua \\
0047 & M Bra 458 & Petiole & Carimagua \\
0050 & M Bra 590 & Petiole & Carimagua \\
0051 & M Ind 33 & Stem & Carimagua \\
0053 & M Ind 33 & Petiole & Villavicencio \\
0079 & M Col 3306-19 & Petiole & Carmen de Bolívar, Bolívar \\
0082 & M Col 1505 & Petiole & Santander de Quilichao, Cauca \\
0088 & CM 4365-3 & Leaf & Santander de Quilichao, Cauca \\
0090 & M Col 1505 & Petiole & Santander de Quilichao, Cauca \\
0101 & Unknown & Stem & Villavicencio \\
0102 & Unknown & Petiole & Villavicencio \\
0114 & M Nga 1 & Petiole & Villavicencio \\
0136 & M Ph 14 & Leaf & Villavicencio \\
0168 & CG 402-11 & Petiole & Villavicencio \\
$1123 C P$ & M Pse 003 & Leaf & Carimagua \\
$983 C P$ & M Pse 010 & Petiole & Carimagua \\
\hline
\end{tabular}

a In the Department of Meta, except where indicated. tion. The entire stalk was then inoculated by spraying with a hand atomizer and placed in a growth chamber with temperatures ranging from 26 to $28^{\circ} \mathrm{C}$. The relative humidity (RH) was kept between 98 and $100 \%$ for $48 \mathrm{~h}$, and afterwards between 50 and $80 \%$. The plants were evaluated 15 days after inoculation.

Molecular characterization of Sphaceloma manihoticola. Tests for molecular characterization were done according to the protocols of Lee and Taylor (11). The sizes of bands were obtained according to the ONE Discan 1.0 program (Dimensional Gel Analysis) 1994-1995.

Extracting DNA. The isolates were placed in liquid medium obtained by filtering V8 juice and incubated, under constant agitation, for 15 days at temperatures between 26 and $28^{\circ} \mathrm{C}$ in the dark. The mycelium was collected and filtered through filter paper Whatman no. 1 under vacuum, was lyophilized $\left(80^{\circ} \mathrm{C}\right.$ in vacuum) for about $2 \mathrm{~h}$, then macerated with liquid nitrogen to obtain a fine and dry powder. A sample of 0.1 to $0.3 \mathrm{~g}$ of macerated mycelium was taken, to which was added $400 \mu \mathrm{l}$ of extraction buffer $(50 \mathrm{mM}$ Tris- $\mathrm{HCl}, \mathrm{pH}$ 7.2; 50 mM EDTA; sodium dodecyl sulfate at 3\%; and 2-mercaptoethanol at 1\%). The solution was mixed with vortex action until a homogeneous consistency was obtained. Subsequently, the suspension was incubated at $65^{\circ} \mathrm{C}$ for $1 \mathrm{~h}$. A solution $(400 \mu \mathrm{l})$ comprising phenol, chloroform, and isoamyl alcohol was added at a ratio of $2: 2: 1$, and the mixture was gently inverted until a homogeneous consistency was obtained. The mixture was then centrifuged for $15 \mathrm{~min}$ at $10,000 \mathrm{rpm}$, and the supernatant was recovered, taking care not to take any of the interphase liquid. Ten $\mu$ of $3 \mathrm{M}$ sodium acetate and 0.54 volumes of isopropanol were then added, mixed by inverting, and left to precipitate for 12 to $14 \mathrm{~h}$ at $-20^{\circ} \mathrm{C}$. The mixture was centrifuged again for $5 \mathrm{~min}$ at $10,000 \mathrm{rpm}$, and the supernatant was decanted.

The resulting pellet was washed with $70 \%$ ethanol, centrifuged for $5 \mathrm{~min}$ at $10,000 \mathrm{rpm}$, and the supernatant discarded. The tubes were then left inverted over sterile paper for $15 \mathrm{~min}$ and dried in a vacuum bell for $1 \mathrm{~h}$. The DNA obtained was resuspended in $100 \mu \mathrm{l}$ of TE buffer $(0.1$ $\mathrm{mM}$ Tris- $\mathrm{HCl}, 10 \mathrm{mM}$ EDTA), $1 \mu \mathrm{l}$ of RNase was added, and the mixture was incubated for $30 \mathrm{~min}$ at $37^{\circ} \mathrm{C}$. The concentration of DNA was determined with a fluorometer (Hoefer DyNA Quant 200; Fluorometer: Hoefer Scientific Instruments, San Francisco, CA), diluted in filtered $(0.2 \mu \mathrm{m})$ sterile, bi-distillate water to a concentration of $5 \mathrm{ng} / \mathrm{ml}$, and stored at $-20^{\circ} \mathrm{C}$.

Amplifying rDNA through PCR. The following reagents were used: a buffer of $10 \times$ enzyme $(50 \mathrm{mM} \mathrm{KCl} ; 10 \mathrm{mM}$ Tris$\mathrm{HCl}, \mathrm{pH} 8.3$; triton $0.1 \%$ ), $0.2 \mathrm{mM}$ dNTPS (dATP, dCTP, dGTP, dTTP), 0.5 mM each 
primer (ITS4 and ITS5), $3 \mathrm{mM}$ magnesium chloride, and $2 \mu \mathrm{l}$ of DNA for each sample. Just before mixing the DNA with the cocktail, 0.625 units of $\mathrm{Taq}$ polymerase pleted with filtered $(0.2 \mu \mathrm{m})$ sterile, bidistillate water to a final volume of $25 \mu \mathrm{l}$. As negative control, we used the mixture of reagents, replacing the DNA with filtered $(0.2 \mu \mathrm{m})$ sterile, bi-distillate water. The samples were covered with $72 \mu$ of sterile mineral oil, and the plate was covered with Vinilpel paper. The plate in which the reaction was to be carried out was placed in a thermocycler PTC-100 (MJ Research, Inc., Watertown, MA), and the following program was set:

1. $95^{\circ} \mathrm{C}$ for $3 \mathrm{~min}$

2. $57^{\circ} \mathrm{C}$ for $30 \mathrm{~s}$

3. $72^{\circ} \mathrm{C}$ for $2 \mathrm{~min}$ enzyme was added and the volume com-

4. $95^{\circ} \mathrm{C}$ for $30 \mathrm{~s}$

5. 24 cycles of steps 2 to 4

6. $50^{\circ} \mathrm{C}$ for $30 \mathrm{~s}$

7. $72^{\circ} \mathrm{C}$ for $10 \mathrm{~min}$

8. $\quad 4^{\circ} \mathrm{C}$

The amplified segments were analyzed by electrophoresis in a gel comprising $1.5 \%$ agar, a buffer of TBE $1 \times$ (trizmabase, boric acid, EDTA, $\mathrm{pH}$ 8.0), and ethidium bromide at $10 \mathrm{mg} / \mathrm{ml}$. The electrophoresis chamber was maintained at a constant $58 \mathrm{~V}$ for $2 \mathrm{~h}$ and $30 \mathrm{~min}$. A marker of $100 \mathrm{bp}$ was included in each gel.

Restriction enzymes. For the analysis with restriction enzymes, a sample of $15 \mu \mathrm{l}$ of the product from the PCR reaction was taken, and $2 \mu \mathrm{l}$ of a buffer of $10 \times$ enzyme and $1 \mu \mathrm{l}$ of restriction enzyme was added. The suspension was incubated for $16 \mathrm{~h}$ at an average temperature of $37^{\circ} \mathrm{C}$, after

Table 2. Linear growth, morphology, and pathogenicity of 33 isolates of Sphaceloma manihoticola to two varieties of cassava (Manihot esculenta)

\begin{tabular}{|c|c|c|c|c|c|c|}
\hline \multirow[b]{3}{*}{ Isolate } & \multirow{2}{*}{\multicolumn{2}{|c|}{ Growth $(\mathbf{c m})^{a}$}} & \multicolumn{2}{|c|}{ Morphology } & \multirow{2}{*}{\multicolumn{2}{|c|}{ Pathogenicity $^{d}$}} \\
\hline & & & \multirow{2}{*}{$\begin{array}{l}\text { Colony } \\
\text { colorb }^{\mathrm{b}}\end{array}$} & \multirow{2}{*}{$\begin{array}{c}\text { Aerial } \\
\text { mycelium }^{\mathrm{c}}\end{array}$} & & \\
\hline & Length & Width & & & M Col 22 & M Ven 77 \\
\hline 0001 & 1.4 & 1.2 & Y-TBr-DR & + & 2.5 & 2.0 \\
\hline 0010 & 2.4 & 2.0 & $\mathrm{Y}-\mathrm{TBr}$ & + & 3.0 & 3.0 \\
\hline 0011 & 2.3 & 2.0 & Y-TG & - & 2.5 & 2.5 \\
\hline 0016 & 2.8 & 1.4 & Y-Br-G & + & 2.0 & 2.5 \\
\hline 0017 & 1.3 & 1.3 & $\mathrm{Y}-\mathrm{TBr}$ & - & 1.5 & 3.0 \\
\hline 0018 & 2.0 & 1.9 & Y-Br-TR & + & 3.0 & 2.5 \\
\hline 0020 & 1.3 & 1.1 & Y & - & 2.5 & 2.0 \\
\hline 0021 & 1.6 & 1.4 & Y-TRo-DR & + & 3.0 & 3.0 \\
\hline 0022 & 2.7 & 2.2 & Y-TBr & + & 3.0 & 3.0 \\
\hline 0024 & 2.4 & 2.0 & Y-TG & + & 3.0 & 3.0 \\
\hline 0026 & 2.8 & 2.2 & Y-BS & + & 3.0 & 3.0 \\
\hline 0033 & 2.8 & 1.8 & BY-BS & - & 2.0 & 3.0 \\
\hline 0035 & 2.0 & 2.0 & $\mathrm{Y}$ & + & 2.5 & 2.5 \\
\hline 0037 & 2.6 & 2.3 & Y-Ro-Tro & + & 3.0 & 3.5 \\
\hline 0040 & 2.4 & 2.0 & Y-DR & + & 2.5 & 3.0 \\
\hline 0041 & 3.0 & 2.5 & Y-Wmy & + & 1.5 & 2.0 \\
\hline 0043 & 1.7 & 1.6 & Y-TBr-Br-DR & + & 2.5 & 2.0 \\
\hline 0046 & 2.1 & 2.0 & $\mathrm{Y}$ & + & 2.5 & 2.5 \\
\hline 0047 & 2.8 & 2.6 & Y-GM & + & 3.0 & 2.5 \\
\hline 0050 & 2.0 & 1.7 & Y-G-TBr & + & 2.5 & 2.5 \\
\hline 0051 & 2.5 & 1.8 & Y-DR-Br & + & 2.0 & 3.0 \\
\hline 0053 & 1.0 & 0.8 & Tbe & - & 2.0 & 2.0 \\
\hline 0079 & 1.9 & 1.9 & B & + & 2.0 & 2.5 \\
\hline 0082 & 2.4 & 2.0 & Y-GM & - & 2.5 & 3.0 \\
\hline 0088 & 1.7 & 1.4 & Y & + & $\mathrm{ND}^{\mathrm{e}}$ & ND \\
\hline 0090 & 0.8 & 0.8 & $\mathrm{Y}$ & + & 2.0 & 3.0 \\
\hline 0101 & 2.1 & 1.8 & Y-DR-Br & + & 2.5 & 3.0 \\
\hline 0102 & 2.6 & 2.4 & TY & - & 3.0 & 3.0 \\
\hline 0114 & 1.9 & 1.6 & $\mathrm{TBr}$ & + & 2.5 & 2.5 \\
\hline 0136 & 2.1 & 1.9 & $\mathrm{Y}-\mathrm{TBr}$ & - & ND & ND \\
\hline 0168 & 1.6 & 1.5 & BY & + & 2.0 & 3.0 \\
\hline $1123 \mathrm{CP}$ & 1.6 & 1.4 & $\mathrm{Y}$ & + & 3.0 & 3.5 \\
\hline $983 \mathrm{CP}$ & 3.3 & 2.2 & Y-G & - & 2.5 & 4.0 \\
\hline Control & ND & ND & ND & ND & 1.0 & 1.0 \\
\hline DMS 5\% & ND & ND & ND & ND & 0.621 & 0.621 \\
\hline
\end{tabular}

a 21 days after placing fungus on medium.

${ }^{\mathrm{b}}$ Color codes for fungal colonies: $\mathrm{B}=$ black, $\mathrm{Br}=$ brown, $\mathrm{BS}=$ black spots, $\mathrm{BY}=$ bright yellow, $\mathrm{DR}$ $=$ dark red, $\mathrm{TBr}=$ different tones of brown, $\mathrm{TG}=$ different tones of green, $\mathrm{TBe}=$ different tones of beige, $\mathrm{TR}=$ different tones of red, $\mathrm{TRo}=$ different tones of rose, $\mathrm{TY}=$ different tones of yellow, $\mathrm{DY}=\tan , \mathrm{G}=$ green, $\mathrm{GM}=$ green $($ margins only), $\mathrm{WMy}=$ white $($ mycelium only), $\mathrm{Ro}=$ rosecolored, $\mathrm{Y}=$ yellow.

$c+=$ presence of aerial mycelium; $-=$ absence of mycelium.

${ }^{\mathrm{d}}$ Average score for damage, rated on a scale where $1=$ plants without visible symptoms, $2=$ some spots or cankers on leaves or petioles, $3=$ cankers on petioles and stems, severe leaf deformation, 4 = elongation, cankers on leaves, petioles, and stems, severe leaf deformation with scald, and $5=$ dieback after severe lengthening.

e Not determined. which $3 \mu \mathrm{l}$ of running buffer was added. A gel comprising $1.4 \%$ agar, a buffer of TBE $1 \times$, and ethidium bromide at $10 \mathrm{mg} / \mathrm{ml}$ was then placed in an electrophoresis chamber for $4 \mathrm{~h}$ at a constant $70 \mathrm{~V}$. In each gel, a marker of known molecular weight $(1 \mathrm{~kb}$ of ladder) was included.

Polymorphism of random amplified DNA (RAPD). Each sample consisted of $2.5 \mu$ l of a buffer of the enzyme, $2.5 \mu$ of dNTPs of $0.2 \mathrm{mM}$ (dATP, dCTP, dGTP, dTTP), $1.2 \mu \mathrm{l}$ of the primer at a concentration of $0.5 \mathrm{mM}, 2.5 \mu \mathrm{l}$ of magnesium chloride at $2.5 \mathrm{mM}$, and $4 \mu \mathrm{l}$ of rDNA. Just before mixing the DNA with the cocktail, 0.625 units of Taq polymerase was added and raised to a final volume of $25 \mu \mathrm{l}$ with filtered $(0.2 \mu \mathrm{m})$ sterile, bi-distillate water. As negative control, we used the mixture of reagents, and the rDNA was replaced by filtered $(0.2 \mu \mathrm{m})$ bi-distilled water. The samples were covered with $72 \mu$ of sterile mineral oil, and the plate was covered with Vinilpel paper. The plate was then placed in a thermocycler and the following program set:

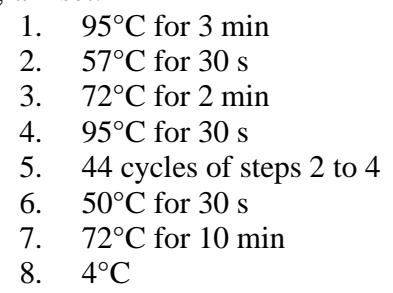

The amplified segments were observed in a gel comprising a $1.4 \%$ agar, a buffer of TBE $1 \times$, and ethidium bromide at 10 $\mathrm{mg} / \mathrm{ml}$. The gel was placed in an electrophoresis chamber at a constant $70 \mathrm{~V}$ for 4 h. In each gel, a marker of known molecular weight (1 kb of ladder) was included. The analysis was performed using NTSYS-pc 1.8 (F. J. Rohlf, Exeter Software, New York) statistical package.

\section{RESULTS}

Isolation and characterization of Sphaceloma manihoticola. Thirty-three isolates were obtained from cassava plants affected by superelongation disease (Table 1). Colonies of all isolates grew slowly (Table 2). A new colony began as a gelatinous or mucous mass that established itself

Table 3. Analysis of variance for pathogenicity evaluated with a scale of damage between 1 and 9 for 31 isolates of Sphaceloma manihoticola obtained from Colombia ${ }^{\mathrm{a}}$

\begin{tabular}{lcc}
\hline Source & df & $\begin{array}{c}\text { Pathogenicity } \\
\text { (mean square) }^{\mathbf{b}}\end{array}$ \\
\hline Replicate & 9 & $0.88 \mathrm{NS}$ \\
Variety & 1 & $4.08^{* *}$ \\
Isolates & 31 & $11.76^{* *}$ \\
Variety $\times$ & 31 & $1.34^{* *}$ \\
isolate & & \\
CV $(\%)$ & 31.33 & \\
\hline
\end{tabular}

a Treatments were arranged in a randomized complete block design with 10 replicates.

$\mathrm{b} * *=P \leq 0.01 ; \mathrm{NS}=$ no significant difference. 
on the medium and then developed as an extension of the mother colony. A colony's growth, both lengthwise and in width, was irregular and highly variable, whether among replicates of a single isolate or among different isolates. Aerial mycelium appeared in a colony between 21 and 28 days after placement on the medium (Table 2). Isolates 0011, 0033, and $983 \mathrm{CP}$ of Carimagua (Meta); 0017 of Puerto López (Meta); 0020 of Granada (Meta); 0082 of Santander de Quilichao (Cauca); and 0053, 0102, and 0136 of Villavicencio (Meta) were late in exhibiting aerial mycelium (at about 28 days). Sometimes the mycelium appeared uniform across the entire colony, and sometimes it appeared only in isolated parts and in different colors: black, brown, yellow, red, green, beige, rose, tan, or white (Table 2). A colony often had several colors. The usual color was yellow, except in colonies of isolates 0079 of Carmen de Bolívar (Bolívar) and 0053 and 0114 of Villavicencio, which were black, beige, and brown, respectively. Areas of new growth changed color as a colony matured. The conidia of all isolates were elliptical and refractive, embedded in a gelatinous matrix (1), with mean dimensions of $5.7 \times$ $3.2 \mu \mathrm{m}$.

The high variability did not permit differentiation of isolates into morphological groups. No significant differences were observed among isolates. Isolates 0022 from Granada; 0024, 0040, 983CP, and 0050 from Carimagua; and 0168 from Villavicencio lost viability over time and could not be recovered.

Pathogenicity. Symptoms include necrotic leaf spots; cankers on leaf veins, petioles, and stems; leaf and stem distortion; and internode elongation of severely affected plants. The reaction of 31 isolates to the susceptible cultivar $\mathrm{M} \mathrm{Col} 22$ ranged from 1.5 to 3.0, and to the resistant cultivar M Ven 77 from 2.0 to 4.0 (Table 2). Cultivar M Col 22 was also tolerant of $29 \%$ of the pathogen population studied and

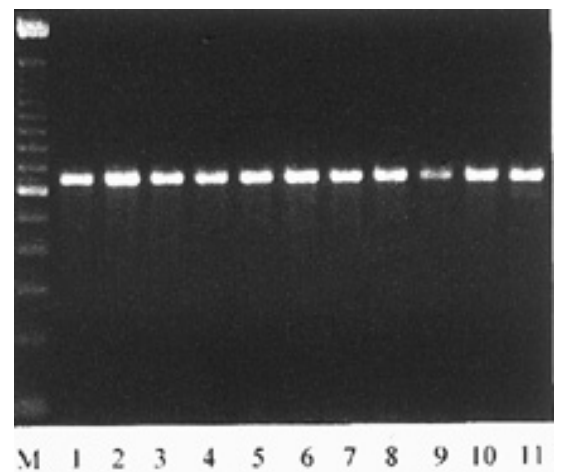

Fig. 1. Amplification of the ITS4 and ITS5 regions of the ribosomal DNA of the fungus Sphaceloma manihoticola. $\mathrm{M}=$ marker $100 \mathrm{bp}$. Lanes 1 to $11=$ isolates from Carimagua, Puerto López, Granada, Villavicencio (Meta), Carmen de Bolívar (Bolívar), and Santander de Quilichao (Cauca). showed an intermediate reaction to the remaining $71 \%$ of that population. Cultivar $\mathrm{M}$ Ven 77 showed a tolerant reaction (score of 2) to $16.2 \%$ of isolates, an intermediate reaction (score of 3 ) to $80.6 \%$, and a susceptible reaction (score $>3$ ) to $3.2 \%$.

For the variable "pathogenicity," the interactions between isolates, variety, and their origin was analyzed by analysis of variance (Tables 3 and 4). Significant differences in pathogenicity were found among the isolates from Carimagua, Granada, Villavicencio, and Puerto López (Meta). In contrast, the isolates from Santander de Quilichao (Cauca) did not show differences. These results indicate host cultivar-pathogen specificity.

Molecular characterization of Sphaceloma manihoticola. Amplification and restriction of $r D N A$. The internal transcribed region of rDNA was amplified with primers ITS4 and ITS5. For all the isolates, a homogeneous band of about 545 bp (Fig.
1) was observed. The product generated by the PCR technique was digested with the endonucleases CfoI, MspI, HinfI, and MseI and presented a pattern of similar bands for all isolates and for each enzyme (Fig. 2, Table 5).

Polymorphisms of random amplified $D N A$. Twenty-five primers were evaluated, of which OPN-18, OPA-03, and OPH-13 were selected because they showed reproducible bands in most of the isolates (Fig $3)$. The analysis showed two genetic lineages: one is homogeneous, comprising mostly isolates from Meta (Fig. 4). Within this group, regional differences were found between Carimagua, Puerto López, Granada, and Villavicencio. The other lineage is heterogeneous and is formed by isolates from several departments. The isolates 0102 of Villavicencio (Meta) and 0090 of Santander de Quilichao (Cauca) were separated from these two lineages, possibly indicating other lineages. The results

Table 4. Analysis of variance for pathogenicity evaluated with a scale of damage between 1 and 9 for 31 isolates of Sphaceloma manihoticola obtained from different departments in Colombia ${ }^{\mathrm{a}}$

\begin{tabular}{lcc}
\hline Source & df & Pathogenicity (mean square) $^{\mathbf{b}}$ \\
\hline Replicate & 9 & $0.88 \mathrm{NS}$ \\
Variety & 1 & $4.08^{* * *}$ \\
Geographic origin of isolates & 6 & $47.06^{* *}$ \\
Carimagua, Meta & 16 & $3.80^{* *}$ \\
Puerto López, Meta & 2 & $2.12^{*}$ \\
Granada, Meta & 2 & $3.76^{* *}$ \\
Villavicencio, Meta & 4 & $2.13^{* *}$ \\
Carmen de Bolívar, Bolívar & 0 & $\ldots$ \\
Santander de Quilichao, Cauca & 1 & $1.40 \mathrm{NS}$ \\
Control isolates & 0 & $\ldots$ \\
Variety $\times$ origin of isolates & 6 & $0.84 \mathrm{NS}$ \\
Variety $\times$ Carimagua, Meta & 16 & $1.46^{* *}$ \\
Variety $\times$ Puerto López, Meta & 2 & $4.36^{* *}$ \\
Variety $\times$ Granada, Meta & 2 & $0.42 \mathrm{NS}$ \\
Variety $\times$ Villavicencio, Meta & 4 & $0.54 \mathrm{NS}$ \\
Variety $\times$ Carmen de Bolívar, Bolívar & 0 & $\ldots$ \\
Variety $\times$ Santander de Quilichao, Cauca & 1 & $\ldots 56 \mathrm{NS}$ \\
Variety $\times$ control isolates & 0 & $\ldots$ \\
CV $(\%)$ & 31.34 & \\
\hline
\end{tabular}

a Treatments were arranged in a randomized complete block design with 10 replicates.

$\mathrm{b} * *=P \leq 0.01 ; *=P \leq 0.05 ; \mathrm{NS}=$ no significant difference.
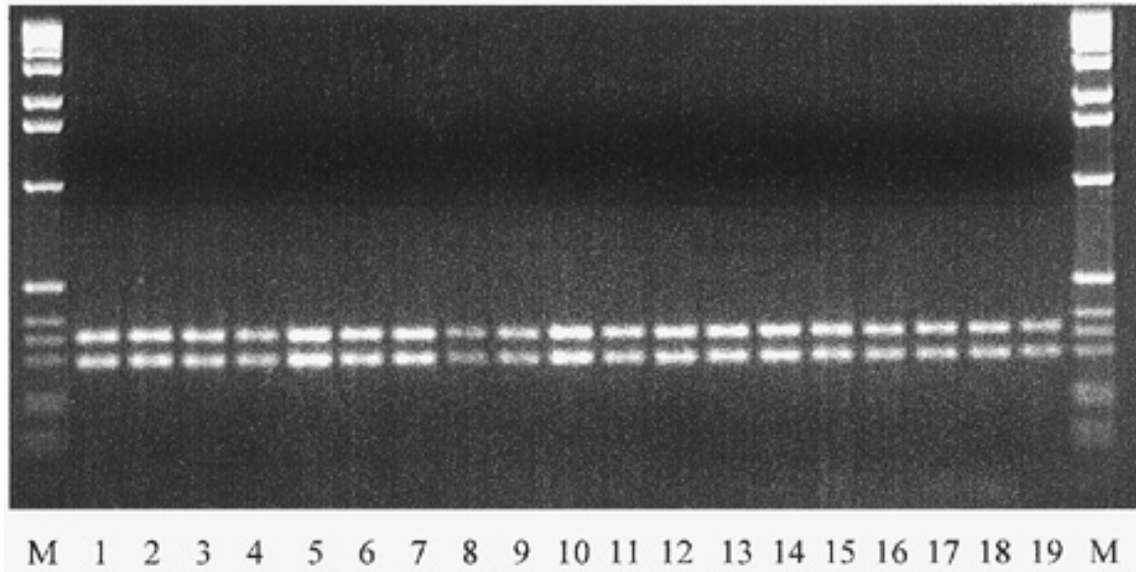

Fig. 2. Electrophoresis of fragments of ITS taken from ribosomal DNA of the fungus Sphaceloma manihoticola and digested by the endonuclease HinfI. Isolate origin: lanes 1 to $13=$ isolates from Carimagua (Meta), lanes 14 and $15=$ isolates from Puerto López, lanes 16 and $17=$ isolates from Granada (Meta), lanes 18 and $19=$ isolates from Villavicencio (Meta), M = marker (1 kb). 
showed that polymorphism exists among the isolates, revealing genetic diversity in the pathogen (13). Isolates with equal indexes of similarity came from different localities, suggesting dissemination of planting materials among the localities and therefore migration of the pathogen and an exchange of genes (12). No correlation was found between morphology and pathogenicity of the fungus, nor between interaction and genetic diversity.

\section{DISCUSSION}

The characterization of a set of isolates that formed a population of the fungus $S$. manihoticola, the causal agent of supere-

Table 5. Sizes of fragments amplified with primers ITS4 and ITS5 and cut with restriction enzymes

\begin{tabular}{|c|c|c|c|c|}
\hline \multirow[b]{2}{*}{ Isolate } & \multicolumn{4}{|c|}{ Restriction enzyme } \\
\hline & CfoI & MspI & MseI & HinfI \\
\hline 0001 & $270,195^{\mathrm{a}}$ & $212,140,125$ & 185,105 & 351,296 \\
\hline 0010 & 269,195 & $212,141,125$ & 185,109 & 355,295 \\
\hline 0011 & 269,194 & $212,141,125$ & 186,110 & 354,294 \\
\hline 0026 & 269,194 & $212,142,126$ & 186,111 & 353,298 \\
\hline 0033 & 268,193 & $212,142,127$ & 186,109 & 347,292 \\
\hline 0035 & 268,193 & $212,143,128$ & 185,110 & 350,295 \\
\hline 0037 & 268,192 & $213,143,128$ & 185,111 & 354,294 \\
\hline 0041 & 267,192 & $213,144,129$ & 185,112 & 357,298 \\
\hline 0043 & 267,192 & $213,143,127$ & 185,110 & 352,296 \\
\hline 0046 & 268,193 & $212,142,127$ & 184,109 & 346,291 \\
\hline 0047 & 275,196 & $214,145,130$ & 185,111 & 353,298 \\
\hline 0051 & 269,195 & $214,144,129$ & 183,112 & 357,296 \\
\hline $1123 \mathrm{cp}$ & 270,194 & $214,144,129$ & 184,110 & 354,294 \\
\hline 0016 & 270,193 & $214,143,128$ & 182,111 & 348,293 \\
\hline 0017 & 270,193 & $214,144,129$ & 185,111 & 357,296 \\
\hline 0018 & 269,195 & $213,145,130$ & 183,112 & 355,295 \\
\hline 0020 & 273,195 & $214,145,130$ & 185,113 & 354,298 \\
\hline 0021 & 272,194 & $213,144,130$ & 184,109 & 357,296 \\
\hline 0053 & 274,195 & $214,144,130$ & 185,114 & 352,296 \\
\hline 0101 & 271,196 & $214,145,131$ & 185,114 & 350,295 \\
\hline 0102 & 272,194 & $213,143,127$ & 185,114 & 353,298 \\
\hline 0114 & 272,193 & $214,145,130$ & 185,114 & 355,295 \\
\hline 0136 & 274,195 & $213,144,129$ & 186,115 & 354,298 \\
\hline 0079 & 274,195 & $214,144,129$ & 185,114 & 355,295 \\
\hline 0082 & 275,196 & $214,144,129$ & 185,114 & 353,298 \\
\hline 0088 & 271,195 & $213,144,129$ & 186,115 & 357,296 \\
\hline 0090 & 274,195 & $213,144,127$ & 186,115 & 356,198 \\
\hline
\end{tabular}

a Sizes in bp, according to Program ONE Discan 1.0.

longation disease in cassava, showed the fungus's morphological, pathogenic, and genetic variability. The morphological characteristics of the isolates evaluated were not sufficiently distinctive to differentiate groups. One reason was that those characteristics were too variable and unstable. The second reason was that conidium size was quite uniform among isolates. These findings corroborate those of other authors, who suggest that any changes found may have been induced by environmental factors $(9,10,19)$. Pathogenicity analyses demonstrated a wide range of host-pathogen interaction, a common phenomenon in heterozygotic crops such as cassava that have polygenic resistance to disease $(8,19)$. It should be emphasized that the two cassava varieties studied responded with an intermediate reaction to most isolates. Such response may be a result of the crop's asexual reproduction, whereby clones are generated with a spectrum of mild reaction (2). Therefore, the genetically variable hosts probably could maintain a genetically variable population of the pathogen (8).

This study is the first to describe this pathogen's molecular characteristics. Thirty-one isolates were identified, all belonging to one species and demonstrating wide genetic diversity. It is possible that this variability was induced by selection of the host. The pathogen has had to continually adapt to the changes in the environment in which it lives, such as the introduction of resistant varieties, fertilizers, crop rotation, and fungicides (2). The latter is realized by conidia being trans-

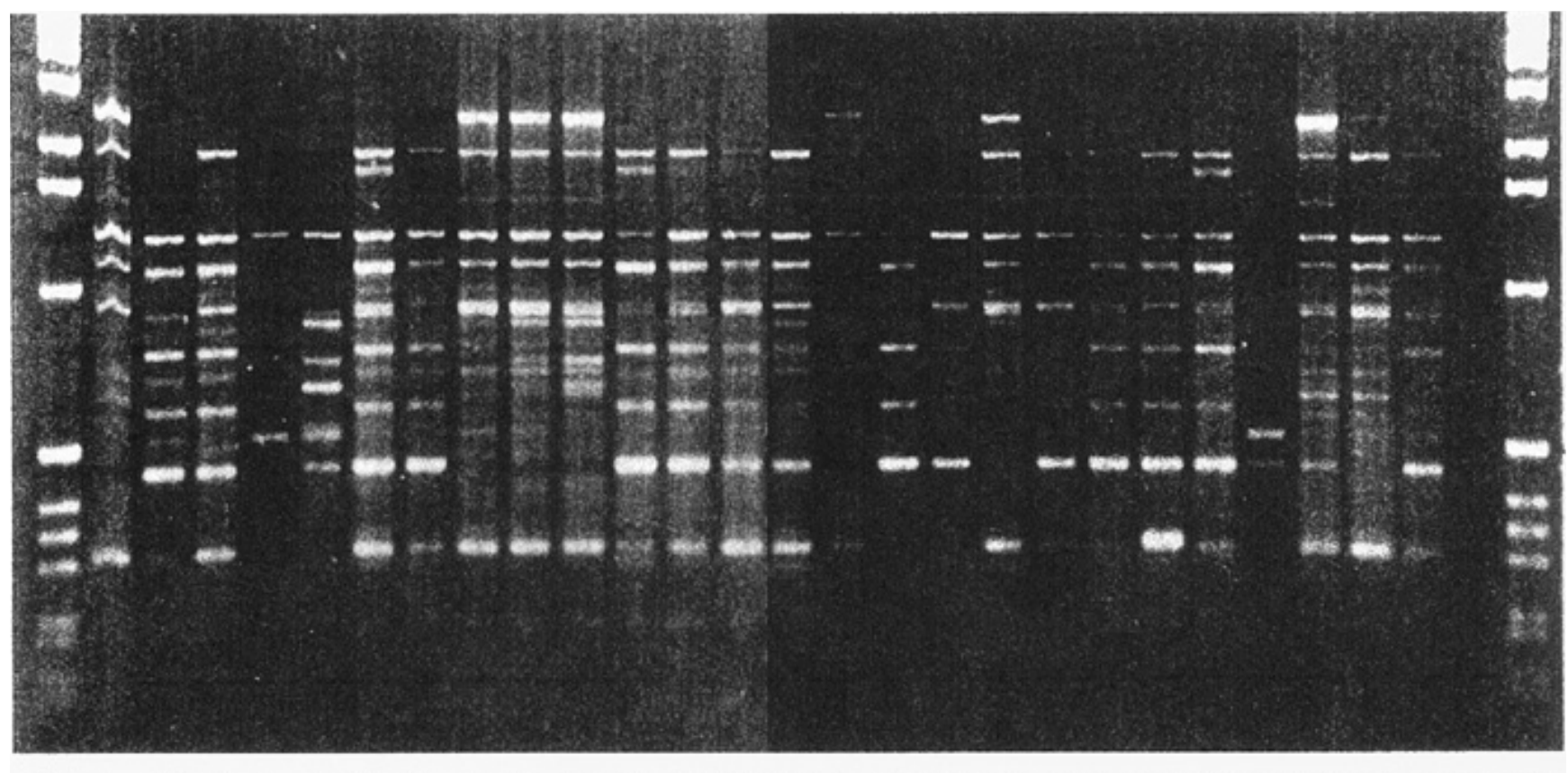

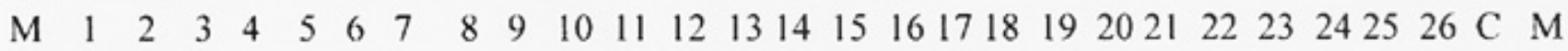

Fig. 3. Band patterns of DNA extracted from the fungus Sphaceloma manihoticola and evaluated with primer OPA-03. Lanes 1 to $13=$ isolates from Carimagua (Meta), lanes 14 and $15=$ isolates from Puerto López, lanes 16 and $17=$ isolates from Granada (Meta), lanes 18 to $22=$ isolates from Villavicencio (Meta), lane 23 = isolates from Carmen de Bolívar (Bolívar), lanes 24 to $26=$ isolates from Santander de Quilichao $(\mathrm{Cauca}), \mathrm{C}=\mathrm{control}, \mathrm{M}=$ marker $(1 \mathrm{~kb})$. 


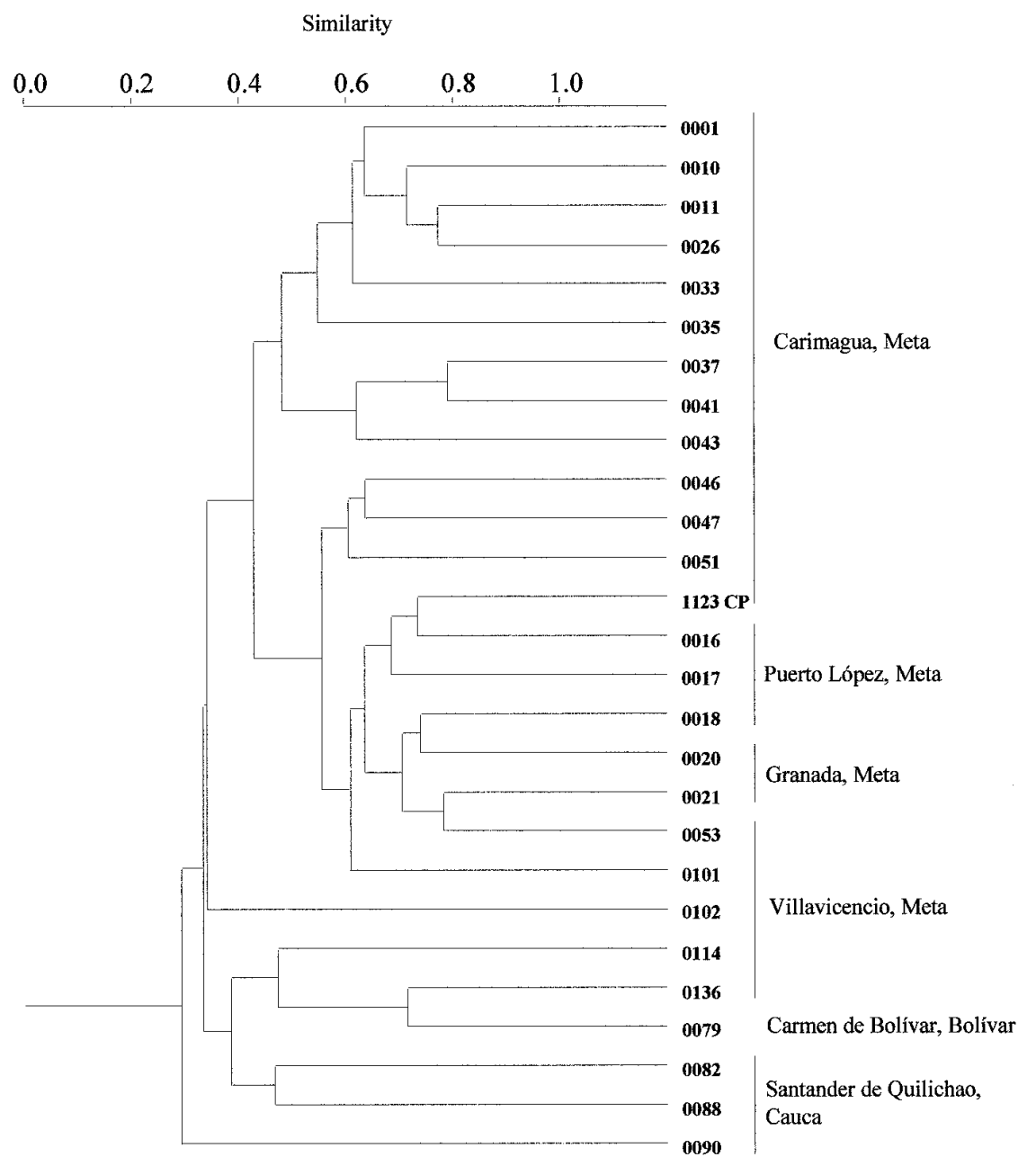

Fig. 4. Phenetic tree of 27 Sphaceloma manihoticola isolates used in this study based on random amplified polymorphic DNA (RAPD) markers. The tree was generated using unweighted pair group method with arithmetic means clustering of a simple genetic distance matrix. The scale represents genetic similarity distance.

ported by rain and wind, thus causing migrations of pathogen populations and, hence, the movement of genes. The result is a movement of new genes and their incorporation into the pathogen's populations, creating a more homogeneous though diverse genotype (14).

This effect would explain why some localities showed more genetic homogeneity, even though they were the sources of the largest number of isolates (e.g., Carimagua and Villavicencio, both in Meta). Indeed, both of these areas contain high levels of potential inoculum throughout the year and are sites for research and exchange of planting material, activities which increase pathogen variability both in these localities and in those farming areas around them (8). These areas show both genetic diversity and genetic similarity among residing isolates of the pathogen. These results help
2. Bitancourt, A., and Jenkins, A. E. 1950. Estudos sôbre as Miriangiales, II. Arq. Inst. Biol. Sao Paulo 20:116.

3. Centro Internacional de Agricultura Tropical. 1973. Sistemas de producción de yuca. Pages 99-100 in: Informe Anual. CIAT, Cali, Colombia.

4. Centro Internacional de Agricultura Tropical. 1996. Cassava: The latest facts about an ancient crop. CIAT, Cali, Colombia.

5. Cock, J. H. 1984. La yuca una fuente básica de energía en los trópicos. Centro Internacional de Agricultura Tropical, Cali, Colombia.

6. Food and Agriculture Organization of the United Nations. 1989. Utilization of tropical foods: Roots and tubers. Compendium on technological and nutritional aspects of processing and utilization of tropical foods, both animal and plant, for purposes of training and field reference. FAO Food and Nutrition $\mathrm{Pa}-$ per 47/3. FAO, Rome.

7. Food and Agriculture Organzation of the United Nations. 1999. April 1999. Database FAOSTAT. FAO. On-line publication.

8. Kawano, K., Umemura, K., and Kano, Y. 1983. Field assessment and inheritance of cassava resistance to superelongation disease. Crop Sci. 23:201-205.

9. Krausz, J. P. 1976. The superelongation disease of cassava. Ph.D. diss. Cornell University, Ithaca, NY.

10. Larios, J., and Moreno, R. A. 1977. Algunas características del hongo que causa la roña de la yuca (Manihot esculenta Crantz) en Costa Rica. Fitopatología 12:1-5.

11. Lee, S. B., and Taylor, J. W. 1990. Isolation of DNA from fungal mycelia and single spores. Pages 282-287 in: PCR protocols. Academic Press, San Diego, CA.

12. Leung, H., Rebeca, J., Nelson, J., and Leach, E. 1993. Population structure of plant pathogenic fungi and bacteria. Adv. Plant Pathol. 10:157-205.

13. McDermott, J. M., McDonald, B. A. 1993 Population genetics of plant pathogenic fungi. BioScience 43:311-319.

14. McDonald, B. A. 1997. The population genetics of fungi: Tools and techniques. Phytopathology 87:448-453.

15. Pérez, S. R. 1989. Experiencias sobre la agroindustria de la yuca en Colombia. Pages 21-26 in: Memorias del congreso Latinoamericano de metodologías aplicadas a proyectos integrados de yuca. Pérez Crespo, C.A. Cali, Colombia.

16. Rondón, G. A., and Aponte, A. 1981. Estudio del superalargamiento de la yuca y búsqueda de cultivares tolerantes a la enfermedad. Fondo Nacional de Investigaciones Agropecuarias (FONAIAP), Maracay, Venezuela.

17. Zeigler, R. S., Alvarez, E., and Lozano, J. C. 1983. Characteristics of cassava resistance to superelongation disease (Elsinoe brasiliensis). Trop. Pest Manage. 29:148-158.

18. Zeigler, R. S., Powell, L. E., and Thurston, H. D. 1980. Gibberellin $\mathrm{A}_{4}$ production by Sphaceloma manihoticola, causal agent of cassava superelongation disease. Phytopathology 70:589-593.

19. Zeigler, R. S., and Lozano, J. C. 1983. Relaciones patogénicas entre algunas especies de Elsinöe y Sphaceloma afectando la yuca (Manihot esculenta) y a otras euphorbiaceas en Centro y Sur América. Fitopatol. Bras. 8:153-171 